\title{
Impacts of boat mooring disturbance on productivity and respiration in rhodolith beds from Catalina Island, USA
}

\section{Impactos de las perturbaciones por el atraque de embarcaciones en la productividad y la respiración de los mantos de rodolitos de la isla Catalina, EUA}

\author{
Dillon Dolinar ${ }^{1}$, Diana Steller ${ }^{2}$, Scott Gabara ${ }^{1,3}$, Billie Beckley ${ }^{1}$, Ju-Hyoung Kim ${ }^{4}$, Matthew Edwards ${ }^{1 *}$ \\ ${ }^{1}$ Department of Biology, San Diego State University, 5500 Campanile Dr. San Diego, CA 92182, USA. \\ 2 Moss Landing Marine Laboratories, 8272 Moss Landing Road, Moss Landing, CA 95039, USA. \\ 3 Department of Environmental Science and Policy, University of California, Davis, USA. \\ ${ }^{4}$ Faculty of Marine Applied Biosciences, Kunsan National University, Gunsan 54150, South Korea.
}

* Corresponding author. E-mail: medwards@sdsu.edu

\begin{abstract}
Aggregations of rhodoliths, habitat-forming, free-living coralline red algae, form beds throughout the world's oceans. On Santa Catalina Island, California, USA, rhodolith beds occur in protected coves where dense networks of moorings support recreational boating activities. The chains and spreader lines associated with these moorings chronically disturb the benthos, crushing the rhodoliths and reducing biodiversity of rhodolith-associated communities. Here, we examine how mooring disturbance affects rhodolith photosynthesis and respiration and characterize rhodolith-associated invertebrate respiration to better understand how this disturbance affects productivity by the ecosystem. To do this, we used a respiration chamber in the laboratory to measure the amount of oxygen produced and/or consumed by undisturbed (intact) rhodoliths, mooring-disturbed ("crushed") rhodolith fragments, and laboratory-crushed rhodoliths, and the amount of oxygen consumed by the dominant rhodolith-associated invertebrate taxa. Our results indicate that rhodolith maximum net productivity is significantly reduced and rhodolith respiration is significantly increased by mooring disturbance in the field, but that crushing of the rhodolith thalli alone does not result in immediate changes to either of these measures. Rather, it appears that chronic crushing of rhodolith thalli, which results in their mortality and rhodolith habitat degradation, is required to elicit these metabolic changes. In addition, we observed variation in respiration rates among the 5 most commonly observed invertebrate taxa within the Catalina Island rhodolith beds, and scaling these respiration rates by each species' abundance in the rhodolith beds and in adjacent mooring-disturbed (degraded) habitats indicated that mooring disturbance results in a decrease in community respiration by approximately $2.61 \mathrm{mg} \mathrm{O} \cdot \mathrm{m}^{-2} \cdot \mathrm{d}^{-1}$, with individual species contributing between $0.05 \mathrm{mg} \mathrm{O}_{2} \cdot \mathrm{m}^{-2} \cdot \mathrm{d}^{-1}$ and $1.84 \mathrm{mg} \mathrm{O} \cdot \mathrm{m}^{-2} \cdot \mathrm{d}^{-1}$ to this decrease. This study provides insight into the consequences of anthropogenic disturbance on productivity and respiration in these ecologically important habitats.
\end{abstract}

Key words: boat mooring, disturbance, productivity, respiration, rhodolith.

RESUMEN. Las agregaciones de rodolitos, algas rojas coralinas de vida libre formadoras de hábitats, forman mantos en todos los océanos del mundo. En la isla Santa Catalina, California, EUA, los mantos de rodolitos se encuentran en ensenadas protegidas donde hay redes de atraques que apoyan las actividades de navegación recreativa. Las cadenas y líneas esparcidoras asociadas a estos atraques perturban crónicamente el bentos, ya que aplastan los rodolitos y reducen la biodiversidad de las comunidades asociadas a los rodolitos. Aquí, examinamos cómo la perturbación por los atraques afecta la fotosíntesis y la respiración de los rodolitos y caracterizamos la respiración de los invertebrados asociados a los rodolitos para comprender mejor cómo esta perturbación afecta la productividad del ecosistema. Para esto, usamos una cámara de respiración en el laboratorio para medir la cantidad de oxígeno producido y/o consumido por los rodolitos no perturbados (intactos), los fragmentos de rodolitos perturbados por atraques ("triturados") y los rodolitos triturados en el laboratorio, y la cantidad de oxígeno consumido por los taxones de invertebrados dominantes asociados a los rodolitos. Nuestros resultados indican que la perturbación causada por los atraques en el campo redujo significativamente la productividad neta máxima de los rodolitos y aumentó significativamente la respiración de estos, pero que la trituración de los talos de los rodolitos por sí sola no ocasionó cambios inmediatos en ninguna de estas medidas. Por lo contrario, parece que la trituración crónica de los talos de rodolitos, la cual ocasiona su muerte y la degradación de su hábitat, es necesaria para provocar estos cambios metabólicos. Además, observamos variaciones en las tasas de respiración entre los 5 taxones de invertebrados más comúnmente observados dentro de los mantos de rodolitos de la isla Catalina, y la extrapolación de estas tasas de respiración con la abundancia de cada especie en los mantos de rodolitos y en los hábitats adyacentes perturbados por los atraques (degradados) indicó que la perturbación de los atraques ocasiona una disminución en la respiración de la comunidad de aproximadamente $2.61 \mathrm{mg} \mathrm{O} \mathrm{O}_{2} \cdot \mathrm{m}^{-2} \cdot \mathrm{d}^{-1}$, con una contribución por especie de entre $0.05 \mathrm{mg} \mathrm{O} \cdot \mathrm{m}^{-2} \cdot \mathrm{d}^{-1}$ y $1.84 \mathrm{mg} \mathrm{O} \cdot \mathrm{m}^{-2} \cdot \mathrm{d}^{-1}$ a esta disminución. Este estudio proporciona una perspectiva de las consecuencias de la perturbación antropogénica en la productividad y la respiración en estos hábitats de importancia ecológica.

Palabras clave: atraque de embarcaciones, perturbación, productividad, respiración, rodolito. 


\section{INTRODUCTION}

Physical disturbances are important in structuring natural ecosystems (Hobbs and Huenneke 1992, Worm et al. 2006, Pickett and White 2013). They can result in increased mortality, changes to the physical environment, altered food web structure, and reduced ecosystem functioning. Although disturbances of moderate strength and/or frequency can result in enhanced biodiversity (Connell 1978), severe and/ or frequent disturbances can result in near-complete mortality of some species (e.g., Edwards and Estes 2006) and ultimately lead to lower biodiversity. Disturbances can be especially important if they result in the loss of foundation species, which provide primary habitat and refuge for other species, enhance biodiversity, modify the environment, and regulate energy flow (Jones et al. 1994). The loss of a foundation species can therefore result in altered ecosystem function (Ellison et al. 2005), which includes controlling rates of primary productivity by the autotrophs, and respiration by the autotrophs, heterotrophs and microbes (del Giorgio et al. 1997, Duarte and Agustí 1998, Edwards et al. 2020). In the coastal marine environment, conspicuous foundation species create coral reefs (Luckhurst and Luckhurst 1978), mangrove habitats (Nagelkerken et al. 2008), kelp forests (Graham 2004, Graham et al. 2007), seagrass beds (Orth et al. 1984), and rhodolith beds (Graham et al. 2016, Tompkins and Steller 2016, Gabara et al. 2018, McConnico et al. 2018).

Rhodoliths (also referred to as maerl) are free-living, coralline red algae (Corallinales) that occur in all the world's oceans (Bosence 1983, Foster 2001). They provide habitat for numerous species on their thallus exteriors (i.e., epiflora and epifauna), within and among their calcified branches (i.e., cryptofauna), and within the underlying sediments they cover (i.e., infauna) (Steller et al. 2003, Grall et al. 2006). When they form large aggregations or "beds" over otherwise soft sedimentary seafloor, they sequester carbon (Mao et al. 2020), increase structural complexity of the environment (Foster 2001, Steller et al. 2003, Gabara et al. 2018), increase larval settlement, retention, and metamorphosis (Steller and Cáceres-Martínez 2009), reduce predation stress (Kamenos et al. 2004a, b), and aggregate food resources for associated consumers (Grall et al. 2006, Gabara 2020). Consequently, they act as foundation species that create important habitat that supports highly diverse communities of commercially and ecologically important finfish and invertebrate species (Foster 2001, Steller et al. 2003), and rhodoliths are therefore increasingly recognized for their conservation value (Airoldi et al. 2008). Further, these invertebrate communities can exhibit high rates of respiration (Newell 1973), and reductions in the abundance and/or body sizes of these species due to habitat degradation can therefore potentially alter net ecosystem productivity and respiration (Brey 2010).

Despite being highly calcified, rhodoliths are branched algae that fragment and grow slowly at a rate of less than $1 \mathrm{~mm} \cdot \mathrm{y}^{-1}$ (Foster 2001). Although rhodoliths require low

\section{INTRODUCCIÓN}

Las perturbaciones físicas son importantes en la estructuración de los ecosistemas naturales (Hobbs y Huenneke 1992, Worm et al. 2006, Pickett y White 2013). Estos pueden ocasionar un aumento en la mortalidad, cambios en el entorno físico, alteración de la estructura de la red alimentaria y reducción del funcionamiento del ecosistema. Aunque las perturbaciones de intensidad y/o frecuencia moderada pueden ocasionar un aumento en la biodiversidad (Connell 1978), las perturbaciones severas y/o frecuentes pueden ocasionar una mortalidad casi completa de algunas especies (e.g., Edwards y Estes 2006) y, con el tiempo, conducir a una menor biodiversidad. Las perturbaciones pueden ser especialmente importantes si ocasionan la pérdida de especies fundamentales, las cuales proporcionan hábitats primarios y refugio para otras especies, mejoran la biodiversidad, modifican el ambiente y regulan el flujo de energía (Jones et al. 1994). Por lo tanto, la pérdida de una especie fundamental puede alterar el funcionamiento del ecosistema (Ellison et al. 2005), que incluye el control de las tasas de productividad primaria por parte de los autótrofos, y la respiración de los autótrofos, heterótrofos y microbios (del Giorgio et al. 1997, Duarte y Agustí 1998, Edwards et al. 2020). En el ambiente marino-costero, las especies fundamentales conspicuas crean arrecifes de coral (Luckhurst y Luckhurst 1978), hábitats de manglar (Nagelkerken et al. 2008), bosques de algas marinas (Graham 2004, Graham et al. 2007), praderas de pastos marinos (Orth et al. 1984) y mantos de rodolitos (Graham et al. 2016, Tompkins y Steller 2016, Gabara et al. 2018, McConnico et al. 2018).

Los rodolitos (también conocidos como maerl) son algas rojas coralinas de vida libre (Corallinales) que se encuentran en todos los océanos del mundo (Bosence 1983, Foster 2001). Estos proporcionan hábitat para numerosas especies en el exterior de sus talos (i.e., epiflora y epifauna), dentro y entre sus ramas calcificadas (i.e., criptofauna) y dentro de los sedimentos subyacentes que cubren (i.e., infauna) (Steller et al. 2003, Grall et al. 2006). Cuando forman grandes agregaciones o "mantos" sobre fondos marinos que de lo contrario serían fondos blandos sedimentarios, los rodolitos secuestran carbono (Mao et al. 2020), aumentan la complejidad estructural del ambiente (Foster 2001, Steller et al. 2003, Gabara et al. 2018), aumentan el asentamiento, la retención y la metamorfosis de las larvas (Steller y Cáceres-Martínez 2009), reducen el estrés por depredación (Kamenos et al. 2004a, b) y forman agregaciones de recursos alimentarios para los consumidores asociados (Grall et al. 2006, Gabara 2020). En consecuencia, actúan como especies fundamentales que crean un hábitat importante que sustenta a comunidades muy diversas de especies de peces e invertebrados de importancia comercial y ecológica (Foster 2001, Steller et al. 2003), por lo que los rodolitos son cada vez más reconocidos por su valor de conservación (Airoldi et al. 2008). Además, estas comunidades de invertebrados pueden exhibir altas tasas 
to moderate physical disturbance for normal development (Steller and Foster 1995), they are susceptible to strong disturbances, from which they are thought to recover slowly. Indeed, anthropogenic impacts from fishing, boat moorings, pollution, anchoring, eutrophication, and sedimentation are all known to have negative effects on rhodolith bed communities (Hall-Spencer and Moore 2000, Tompkins and Steller 2016). In particular, chronic crushing from boat mooring chains has been identified as particularly detrimental to rhodolith beds on Catalina Island, California, USA, in that it reduces live rhodolith cover and habitat structural complexity, increases sedimentation, and reduces biodiversity, all with long-lasting effects on habitat quality (Tompkins and Steller 2016, Gabara et al. 2018). What remains unclear is how this crushing impacts other aspects of ecosystem functioning, such as primary productivity and respiration. To address this, we ask 3 integrated questions: (1) Do productivity and respiration differ between "intact" rhodoliths from undisturbed locations and rhodoliths that have been crushed into fragments by mooring chains, (2) Does crushing of the rhodolith thalli alter their productivity and respiration, and (3) What are the respiration rates of the most common invertebrate epifauna that inhabit the rhodolith beds? We combine our estimates of invertebrate respiration for the 5 most commonly observed epibenthic species with general estimates of their abundances in Catalina rhodolith beds and in adjacent mooring-disturbed (degraded) habitats to model how reductions in their abundance may contribute to changes in ecosystem respiration. Our overarching goal is to better understand how chronic disturbance from boat moorings affects productivity and respiration of rhodoliths and the species that they support.

\section{MATERIALS AND METHOdS}

\section{Study Site}

Catalina Island, USA $\left(33.40^{\circ} \mathrm{N}, 118.40^{\circ} \mathrm{W}\right)$, is one of California's top recreational boating destinations, with about one million visitors each year (https://www.catalinatours.com/catalina-island-by-the-numbers/), over 50,000 of whom stay on private boats and use the moorings provided by Catalina's harbors. The island is roughly $32 \mathrm{~km}$ south of the city of Los Angeles and is part of the California Channel Islands. It is oriented Northwest-Southeast and experiences the warm water from the Southern California Countercurrent. While the nearshore habitat around the island is primarily rocky reef dominated by kelp and rockweed forests that are interspersed with sandy habitats, 7 rhodolith beds were recently identified in shallow $(5-25 \mathrm{~m})$ soft-bottom, protected bays where high densities of recreational boat mooring systems also occur (Tompkins 2011, Tompkins and Steller 2016). The chains on these moorings have led to crushing of the rhodoliths and severe degradation of the rhodolith beds over large swaths of the benthos (Gabara et de respiración (Newell 1973), y las reducciones en la abundancia y/o el tamaño corporal de estas especies debido a la degradación del hábitat pueden, por lo tanto, alterar potencialmente la productividad y la respiración netas del ecosistema (Brey 2010).

A pesar de estar altamente calcificados, los rodolitos son algas ramificadas que se fragmentan y crecen lentamente a una velocidad de menos de $1 \mathrm{~mm} \cdot \mathrm{año}^{-1}$ (Foster 2001). Los rodolitos requieren una alteración física de baja a moderada para su desarrollo normal (Steller y Foster 1995); sin embargo, son susceptibles a perturbaciones fuertes, de las cuales se piensa que se recuperan lentamente. De hecho, se sabe que los impactos antropogénicos de la pesca, los atraques de embarcaciones, la contaminación, el anclaje, la eutrofización y la sedimentación tienen un efecto negativo en las comunidades de mantos de rodolitos (Hall-Spencer y Moore 2000, Tompkins y Steller 2016). En particular, el aplastamiento crónico por las cadenas de atraque de embarcaciones se ha identificado como particularmente perjudicial para los mantos de rodolitos en la isla Catalina, California, EUA, ya que reduce la cobertura de rodolitos vivos y la complejidad estructural del hábitat, incrementa la sedimentación y reduce la biodiversidad, todo con efectos duraderos en la calidad del hábitat (Tompkins y Steller 2016, Gabara et al. 2018). Lo que no está claro es cómo este aplastamiento impacta otros aspectos del funcionamiento del ecosistema, como la productividad primaria y la respiración. Para abordar esto, hacemos 3 preguntas integradas: (1) ¿Difieren la productividad y la respiración entre los rodolitos "intactos" de lugares no perturbados y los rodolitos que han sido triturados y convertidos en fragmentos por cadenas de atraque? (2) ¿La trituración de los talos de los rodolitos altera su productividad y respiración? (3) ¿Cuáles son las tasas de respiración de los invertebrados epifaunales más comunes que habitan en los mantos de rodolitos? Combinamos nuestras estimaciones de la respiración de invertebrados para las 5 especies epibentónicas más comúnmente observadas con las estimaciones generales de sus abundancias en los mantos de rodolitos de Catalina y en hábitats adyacentes alterados por los atraques (degradados) para modelar cómo las reducciones en sus abundancias podrían contribuir a cambios en la respiración del ecosistema. Nuestro objetivo general es comprender mejor cómo la perturbación crónica de los atraques de las embarcaciones afecta la productividad y la respiración de los rodolitos y a las especies que sustentan.

\section{MATERIALES Y MÉTODOS}

\section{Área de estudio}

La isla Catalina, EUA $\left(33.40^{\circ} \mathrm{N}, 118.40^{\circ} \mathrm{W}\right)$, es uno de los principales destinos de navegación recreativa de California, con aproximadamente un millón de visitantes cada año (https://www.catalinatours.com/catalina-island-bythe-numbers/), de los cuales más de 50,000 se alojan en 
al. 2018). The result of chronic crushing by these chains is visible areas of white, crushed carbonate rhodolith sand that support lower abundances of invertebrate species (Gabara et al 2018). Crushed rhodolith fragments (hereafter CRF), which are pigmented and alive but otherwise reduced in size relative to intact rhodoliths (Kim et al. 2020), occur at the edges of these disturbed areas, where they abut the undisturbed rhodolith beds. CRF hereafter consists of both broken rhodolith branches and rhodolith core areas.

\section{Sample collection}

Approximately 200 intact rhodoliths (Lithothamnion australe) (Foslie) and approximately $100 \mathrm{~g}$ wet weight (ww) of CRF were collected from 4-10 m water depth at the Isthmus Reef rhodolith bed in January 2019 (see map in Tompkins and Steller 2016). The intact rhodoliths were collected from within the center of a living bed (i.e., where there was approximately $100 \%$ cover of undisturbed rhodoliths) and the CRF were collected at the interface of this bed in an area where boat mooring chains physically contact the benthos and crush the living rhodoliths (Fig. 1). In addition, 10 haphazardly selected individuals of the 5 most common epibenthic invertebrates observed in the rhodolith beds at Catalina Island were collected from within 3 rhodolith beds at Isthmus Reef, Emerald Bay, and Cherry Cove (see map in Tompkins and Steller 2016). These included wavy turban snail (Megastraea undosa), cone snail (Californiconus californicus), top shell snail (Lirularia sp.), white urchin (Lytechinus pictus), and the California aglaja (Navanax inermis). All organisms were transported to the Wrigley Institute for Environmental Science (WIES) in darkened coolers and immediately placed in flow-through seawater tables in an indoor laboratory, where they were held under ambient temperature conditions until processing (within $24 \mathrm{~h}$ ).

\section{Effects of crushing on rhodolith productivity and respiration}

To examine if productivity and respiration differ between naturally occurring undisturbed rhodoliths and rhodoliths that have been crushed into fragments by boat mooring chains, we compared maximum net productivity and respiration between intact rhodoliths and CRF. Specifically, 9 replicate intact rhodoliths of similar size $(1.80 \pm 0.91 \mathrm{~g} \mathrm{ww})$ (mean \pm $\mathrm{SD})$ and 10 replicate similarly sized $(1.71 \pm 0.76 \mathrm{~g} \mathrm{ww})$ samples of CRF were obtained from the laboratory holding tank, blotted dry with a paper towel, and weighed. Then, working with one replicate at a time, each rhodolith or CRF sample was placed into a $96-\mathrm{mL}$ water-jacketed respiration chamber that was connected to the flow-through seawater system at WIES, which kept the chamber at ambient seawater temperature during the measurements $\left(15.9 \pm 0.5^{\circ} \mathrm{C}\right)$. The respiration chamber was connected to a YSI OBOD probe barcos privados y utilizan los atraques proporcionados por los puertos de Catalina. La isla está, aproximadamente, a $32 \mathrm{~km}$ al sur de la ciudad de Los Ángeles y es parte de las islas del Canal de California. La isla tiene una orientación noroeste-sureste y recibe el agua cálida de la contracorriente del sur de California. Aunque el hábitat cerca de la costa que rodea la isla es principalmente arrecife rocoso dominado por bosques de macroalgas y de algas de roca que se intercalan con hábitats arenosos, 7 mantos de rodolitos fueron identificados recientemente en bahías protegidas someras $(5-25 \mathrm{~m})$ de fondo blando donde también hay altas densidades de sistemas de atraques para embarcaciones recreativas (Tompkins 2011, Tompkins y Steller 2016). Las cadenas de estos atraques han provocado el aplastamiento de los rodolitos y la grave degradación de los mantos de rodolitos en grandes franjas del bentos (Gabara et al. 2018). El aplastamiento crónico por estas cadenas resulta en áreas visibles de arena blanca de carbonato de rodolito triturado que soportan una menor abundancia de especies de invertebrados (Gabara et al. 2018). Los fragmentos de rodolitos triturados (en lo sucesivo FRT), los cuales están pigmentados y vivos pero reducidos en tamaño comparados con los rodolitos intactos (Kim et al. 2020), se encuentran en los bordes de estas áreas perturbadas, donde colindan con los mantos de rodolitos intactos. En lo sucesivo, FRT consta tanto de ramas rotas de rodolitos como de partes del núcleo de los rodolitos.

\section{Recolección de las muestras}

Se recolectaron aproximadamente 200 rodolitos intactos (Lithothamnion australe) (Foslie) y aproximadamente $100 \mathrm{~g}$ de peso húmedo (ph) de FRT a 4-10 $\mathrm{m}$ de profundidad en el manto de rodolitos del arrecife Isthmus en enero de 2019 (ver mapa en Tompkins y Steller 2016). Los rodolitos intactos se recolectaron del centro de un manto vivo (i.e., donde había aproximadamente un 100\% de cobertura de rodolitos intactos) y los FRT se recogieron en la interfaz de este manto en un área donde las cadenas de atraque de embarcaciones tienen contacto físico con el bentos y aplastan los rodolitos vivos (Fig. 1). Además, 10 individuos seleccionados aleatoriamente de los 5 invertebrados epibentónicos más comúnmente observados en los mantos de rodolitos en la isla Catalina fueron recolectados del interior de 3 mantos de rodolitos en el arrecife Isthmus, la bahía Emerald y la bahía Cherry (ver mapa en Tompkins y Steller 2016). Estos incluían el caracol panocha (Megastraea undosa), el caracol cono (Californiconus californicus), el caracol concha superior (Lirularia sp.), el erizo blanco (Lytechinus pictus) y el aglaja de California (Navanax inermis). Todos los organismos fueron transportados al Instituto Wrigley de Ciencias Ambientales (WIES, por sus siglas en inglés) en hieleras oscuras y colocados inmediatamente en mesas de agua de mar de flujo continuo en un laboratorio cerrado, donde se mantuvieron a temperatura ambiente hasta su procesamiento (en las $24 \mathrm{~h}$ siguientes). 


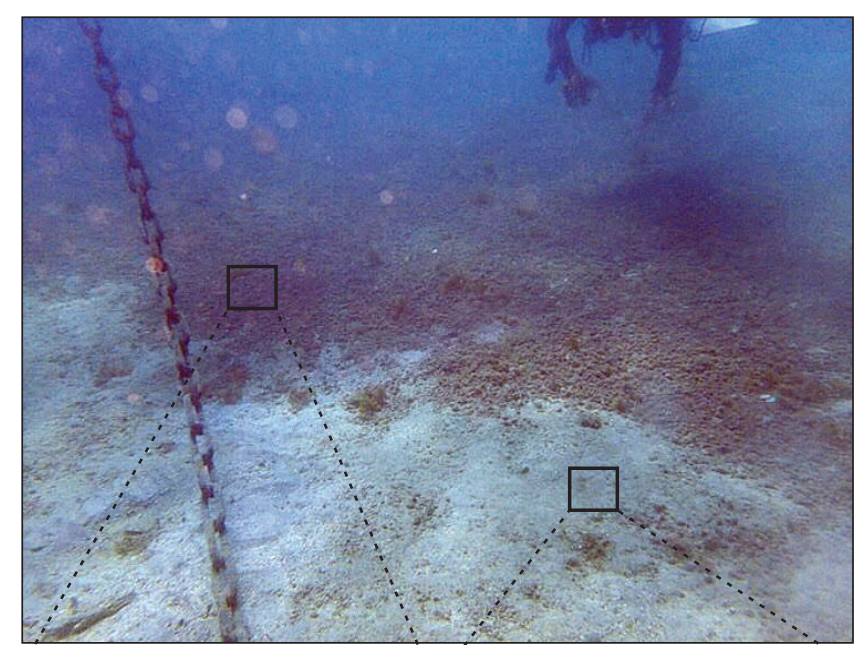

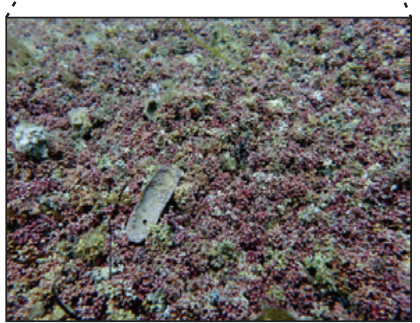

Intact (undisturbed) rhodoliths

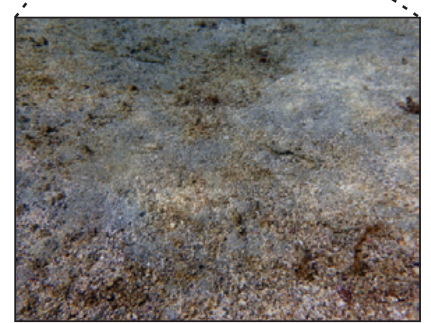

Mooring-distubed CRF
Figure 1. Photo showing undisturbed (intact) rhodolith bed and mooring-disturbed crushed rhodolith fragments (CRF). The undisturbed rhodolith bed is pictured with inset showing intact rhodoliths on the left panel, and the mooring-disturbed CRF habitat is pictured with inset showing CRF on the right panel. The interface between the 2 habitats is clearly delineated.

Figura 1. Fotografía que muestra un manto de rodolito no perturbado (intacto) y fragmentos de rodolitos triturados (CRF) perturbados por atraques. El manto de rodolitos no perturbado se indica con un recuadro que muestra los rodolitos intactos en el panel izquierdo, y el hábitat de los FRT perturbados por atraques se muestra con un recuadro que los resalta en el panel derecho. La interfaz entre los 2 hábitats está claramente delineada.

(self-stirring Optical BOD probe) that measured seawater dissolved oxygen (DO) within the chamber every $5 \mathrm{~s}$ using a ProODO optical DO meter (YSI; Yellow Springs, OH, USA). The respiration chamber was placed in front of a halogen light source (PAR38 Wide Flood 60 deg. soft white light bulb) that provided an irradiance of approximately $350 \mu \mathrm{mol}$ photons $\cdot \mathrm{m}^{-2} \cdot \mathrm{s}^{-1}$ to the chamber's interior, which exceeded L. australe's saturation irradiance and allowed for estimates of maximum photosynthesis without inducing photoinhibition (Kim et al. 2020). To first estimate initial dark respiration, the chamber was covered with an opaque black cloth and decreases in DO within the chamber were recorded for $15 \mathrm{~min}$. The cloth was then removed, exposing the rhodoliths and/or CRF to saturating irradiances, and net productivity was subsequently measured by recording increases in

\section{Efectos de la trituración en la productividad y la respiración del rodolito}

Para examinar si la productividad y la respiración difieren entre los rodolitos no perturbados de ambientes naturales y los rodolitos que fueron triturados en fragmentos por las cadenas de atraque de embarcaciones, comparamos la productividad y respiración máxima neta entre los rodolitos intactos y los FRT. Específicamente, se obtuvieron 9 réplicas de rodolitos intactos de tamaños similares $(1.80 \pm 0.91 \mathrm{~g} \mathrm{ph})$ (media \pm desviación estándar) y 10 réplicas de muestras de FRT de tamaños similares $(1.71 \pm 0.76 \mathrm{~g} \mathrm{ph})$ del tanque de almacenamiento del laboratorio; estas se secaron con una toalla de papel y se pesaron. Posteriormente, trabajando con una réplica a la vez, cada muestra de rodolito o FRT fue colocada en una cámara de respiración con chaqueta de agua de $96 \mathrm{~mL}$ conectada al sistema de flujo continuo de agua de mar en WIES, que mantuvo la cámara a la temperatura del ambiente del agua de mar durante las mediciones $\left(15.9 \pm 0.5^{\circ} \mathrm{C}\right)$. La cámara de respiración estaba conectada a una sonda óptica BOD (OBOD, por sus siglas en inglés) de YSI (OBOD con agitación automática) que midió el oxígeno disuelto (OD) en el agua de mar dentro de la cámara cada $5 \mathrm{~s}$ con un medidor de OD óptico ProODO (YSI; Yellow Springs, OH, EUA). La cámara de respiración se colocó frente a una fuente de luz halógena (RFA38 iluminación amplia 60 grados, bombilla de luz blanca suave) que proporcionó una irradiancia de aproximadamente $350 \mu \mathrm{mol}$ fotones $\cdot \mathrm{m}^{-2} \cdot \mathrm{s}^{-1}$ al interior de la cámara, la cual excedió la irradiancia de saturación de L. australe y permitió estimar la fotosíntesis máxima sin inducir la fotoinhibición (Kim et al. 2020). Para estimar la respiración oscura inicial primero, se cubrió la cámara con una tela negra opaca y se registró la disminución en el OD dentro de la cámara durante $15 \mathrm{~min}$. Posteriormente, se retiró la tela para exponer los rodolitos y/o FRT a irradiancias de saturación, y subsecuentemente se midió la productividad neta registrando los aumentos de OD durante los siguientes 15 min. Después de tomar las mediciones, los rodolitos y/o FRT fueron extraídos y pesados. La productividad neta y la respiración para cada muestra de rodolito y FRT se determinaron calculando la tasa de cambio del OD $\left(\Delta \mathrm{mg} \mathrm{O}_{2} \cdot \mathrm{g}\right.$ talo $\left.\mathrm{ph}^{-1} \cdot \mathrm{s}^{-1}\right)$ dentro de la cámara usando regresiones lineales separadas. Estas estimaciones fueron extrapoladas con la biomasa de cada rodolito y luego expandidas para reflejar las tasas por hora.

Para examinar si la trituración física de los talos de los rodotlitos afecta su máxima productividad y/o la respiración neta, trituramos rodolitos intactos en el laboratorio de manera experimental y medimos los cambios en sus metabolismos. Específicamente, se obtuvieron 6 rodolitos de tamaños similares $(1.51 \pm 0.66 \mathrm{~g} \mathrm{ph})$ del tanque de retención del laboratorio, se secaron con papel secante y se pesaron. Cada rodolito se colocó en la cámara de respiración y se midió su respiración y la productividad neta como se describió anteriormente. Posteriormente, cada rodolito fue retirado de la cámara de respiración y triturado de manera experimental en 
DO over the following $15 \mathrm{~min}$. Following measurement, the rhodoliths and/or CRF were removed and weighed. Respiration and net productivity for each rhodolith and CRF sample were determined by calculating the rate of change in DO $\left(\Delta \mathrm{mg} \mathrm{O}_{2} \cdot \mathrm{g}\right.$ thallus $\mathrm{ww}^{-1} \cdot \mathrm{s}^{-1}$ ) within the chamber using separate linear regressions. These estimates were scaled by each rhodolith's biomass and then expanded to reflect hourly rates.

To examine if physical crushing of the rhodolith thalli affects their maximum net productivity and/or respiration, we experimentally crushed intact rhodoliths in the laboratory and measured changes in their metabolisms. Specifically, 6 rhodoliths of similar size $(1.51 \pm 0.66 \mathrm{~g} \mathrm{ww})$ were obtained from the laboratory holding tank, blotted dry with a paper towel, and weighed. Each rhodolith was placed in the respiration chamber and its respiration and net productivity was measured as described above. Following this, each rhodolith was removed from the respiration chamber and experimentally crushed into small $(<0.25 \mathrm{~cm}) \mathrm{CRF}$ by dropping a 60-g lead fishing weight on it over approximately $1 \mathrm{~min}$. These CRF, including the core, were returned to the respiration chamber and their respiration and net productivity was re-measured. The differences in productivity $\left(\Delta_{\text {Prod }}\right)$ and respiration $\left(\Delta_{\text {Res }}\right)$ between the pre-crushing (first) measurements and post-crushing (second) measurements were then determined for each intact and crushed rhodolith. To ensure any differences observed between the 2 physiology measurements were indeed due to crushing and not simply due to the rhodoliths and/or CRF being measured a second time (i.e., a handling effect), the 9 intact rhodoliths that were used to compare undisturbed rhodoliths and mooring disturbed CRF (discussed above) were also measured a second time, which served as a procedural (handling) control. To do this, each of those rhodoliths were removed from the respiration chamber immediately after measurement, left out for $1 \mathrm{~min}$ (the approximate time it took to crush the rhodoliths with the lead weight), and then returned to the chamber, where its respiration and net productivity were re-measured. This determined there were little-to-no differences between the first and second measurements (see Results), which informed us that any differences observed in the CRF were indeed due to crushing the thalli.

\section{Quantifying rhodolith-associated invertebrate respiration}

Respiration rates of $M$. undosa, C. californicus, Lirularia sp., L. pictus, and $N$. inermis were quantified using a respiration chamber in the laboratory. Specifically, 10 individuals of each species were chosen haphazardly from the holding tank and placed individually in a 1-L water-jacketed respiration chamber similar to the one described above. The chamber was connected to the WIES flow-through seawater system, which kept the chamber seawater at ambient temperature $\left(15.9 \pm 0.5^{\circ} \mathrm{C}\right)$. Respiration for each organism was estimated by measuring changes in DO within the chamber for $15 \mathrm{~min}$ under ambient light $\left(>100 \mu \mathrm{mol}\right.$ photons $\left.\cdot \mathrm{m}^{-2} \cdot \mathrm{s}^{-1}\right)$.
FRT pequeños $(<0.25 \mathrm{~cm})$ dejando caer un peso de plomo de pesca de $60 \mathrm{~g}$ sobre este durante aproximadamente $1 \mathrm{~min}$. Estos FRT, incluido el núcleo, fueron devueltos a la cámara de respiración y se volvió a medir su respiración y productividad neta. A continuación, se determinaron las diferencias en la productividad $\left(\Delta_{\text {Prod }}\right)$ y la respiración $\left(\Delta_{\text {Res }}\right)$ entre las mediciones pre-trituración (primeras) y post-trituración (segundas) para cada rodolito intacto y triturado. Para asegurar que cualquier diferencia observada entre las 2 mediciones fisiológicas se debía realmente al aplastamiento y no simplemente a que los rodolitos y/o el FRT se midieron por segunda vez (i.e., un efecto de la manipulación), los 9 rodolitos intactos que se usaron para comparar rodolitos no perturbados y los FRT perturbados por los atraques (discutidos anteriormente) también fueron medidos una segunda vez, lo que sirvió como un control del procedimiento (manipulación). Para esto, cada uno de estos rodolitos fue retirado de la cámara de respiración inmediatamente después de la medición, dejado afuera durante $1 \mathrm{~min}$ (el tiempo aproximado que tomó triturar los rodolitos con el peso de plomo) y posteriormente devuelto a la cámara, donde su respiración y la productividad neta se volvió a medir. Esto determinó que había poca o ninguna diferencia entre la primera y la segunda medición (ver Resultados), lo que nos informó que cualquier diferencia observada en los FRT se debía efectivamente al aplastamiento de los talos.

\section{Cuantificación de la respiración de los invertebrados asociados a rodolitos}

Las tasas de respiración de $M$. undosa, C. californicus, Lirularia sp., L. pictus y $N$. inermis se cuantificaron utilizando una cámara de respiración en el laboratorio. Específicamente, se eligieron al azar 10 individuos de cada especie del tanque de retención y se colocaron de manera individual en una cámara de respiración con una chaqueta de agua de 1 L similar a la descrita anteriormente. La cámara se conectó al sistema de flujo continuo de agua de mar de WIES, que mantuvo el agua de mar de la cámara a temperatura ambiente $\left(15.9 \pm 0.5^{\circ} \mathrm{C}\right)$. La respiración de cada organismo se estimó midiendo los cambios en el OD dentro de la cámara durante 15 min bajo luz ambiental $\left(>100 \mu \mathrm{mol}\right.$ fotones $\left.\cdot \mathrm{m}^{-2} \cdot \mathrm{s}^{-1}\right)$. A continuación, se sacó al organismo de la cámara, se secó el exceso de agua con papel secante y se pesó como gramos de ph. Para evaluar si los cambios observados en el OD dentro de las cámaras se debieron a factores distintos a la respiración de los invertebrados (i.e., el metabolismo de microalgas y/o microbios), la cámara se llenó con agua de mar como se indicó anteriormente y los cambios en el OD se midieron durante 15 min dentro de la cámara sin los invertebrados. Esto se repitió 5 veces, lo que indicó que el cambio en el OD dentro de la cámara sin los invertebrados fue de poco a nulo. Por lo tanto, para modelar cómo la pérdida de estas 5 especies por la degradación del hábitat de rodolitos afecta la respiración del ecosistema, combinamos nuestras mediciones 
The organism was then removed from the chamber, blotted dry of excess water using a paper towel, and weighed as grams ww. To evaluate if any observed changes in DO within the chambers resulted from factors other than invertebrate respiration (i.e., microalgae and/or microbe metabolism), the chamber was filled with seawater as above and changes in DO were measured for $15 \mathrm{~min}$ within the chamber in the absence of the invertebrates. This was repeated 5 times, which indicated that little-to-no changes in DO occurred within the chamber in the absence of invertebrates. Therefore, to model how the loss of these 5 species due to rhodolith habitat degradation affects ecosystem respiration, we combined our respiration measurements with estimates of each species' density in rhodolith beds and adjacent mooring-degraded habitats as described by Gabara et al. (2018) (see Table 1).

\section{Statistical analysis}

Variation in net productivity and respiration among the undisturbed (intact) rhodoliths, the mooring-disturbed CRF, and laboratory-crushed rhodoliths were evaluated with separate analyses of variance (ANOVA). Following this, a priori comparisons between pairs of the 3 treatments were evaluated with Fisher's least significant difference (LSD) post hoc tests. Differences in net productivity $\left(\Delta_{\mathrm{Prod}}\right)$ and respiration $\left(\Delta_{\text {Res }}\right)$ between pre- and post-crushing in the laboratory were each evaluated with separate paired $t$-tests. Prior to analyses, all data were checked for normality using probability plots and for equal variances using Bartlett's test (for respiration) and Levine's test (for productivity), with the latter used because data for productivity in the laboratory-crushed rhodoliths exhibited minor departures from normality. All statistical analyses were done using R-Studio v.1.1.463, R v.3.5.2, and SYSTAT v.6.0.

\section{RESULTS}

\section{Effects of laboratory crushing on rhodolith productivity and respiration}

Net productivity was significantly different among the undisturbed (intact) rhodoliths (0.032 \pm $\left.0.023 \mathrm{mg} \mathrm{O}{ }_{2} \cdot \mathrm{g}^{-1} \cdot \mathrm{h}^{-1}\right)$, the mooring-disturbed CRF $(-0.002 \pm$ $\left.0.030 \mathrm{mg} \mathrm{O} \cdot \mathrm{g}^{-1} \cdot \mathrm{h}^{-1}\right)$, and the laboratory-crushed rhodoliths $\left(0.026 \pm 0.023 \mathrm{mg} \mathrm{O}{ }_{2} \cdot \mathrm{g}^{-1} \cdot \mathrm{h}^{-1}\right)\left(\right.$ ANOVA: $F_{2,21}=8.468, P=$ 0.002 ). Specifically, net productivity was significantly lower in the mooring-disturbed CRF than in the undisturbed (intact) rhodoliths (Fisher's LDS: $P=0.001$ ) and in the laboratory-crushed rhodoliths $(P=0.048)$, but it did not differ between the undisturbed (intact) rhodoliths and the laboratory-crushed rhodoliths $(P=0.129)$ (Fig. 2). In fact, the mooring-disturbed CRF exhibited net respiration, while the intact rhodoliths and the rhodoliths that were crushed in the lab both exhibited net productivity (Fig. 2). In addition, respiration was also significantly different among the de respiración con las estimaciones de la densidad de cada especie en los mantos de rodolitos y hábitats adyacentes degradados por atraques como fue descrito por Gabara et al. (2018) (ver Tabla 1).

\section{Análisis estadístico}

Se evaluó la variación en la productividad neta y la respiración entre los rodolitos no perturbados (intactos), los FRT perturbados por los atraques y los rodolitos triturados en el laboratorio con análisis de varianza separados (ANDEVA). Posteriormente, se evaluaron las comparaciones a priori entre pares de los 3 tratamientos con las pruebas post hoc de la diferencia mínima significativa (DMS) de Fisher. Las diferencias en la productividad neta $\left(\Delta_{\text {Prod }}\right)$ y la respiración $\left(\Delta_{\text {Res }}\right)$ entre las muestras pre-trituración y post-trituración en el laboratorio se evaluaron cada una con pruebas $t$ pareadas separadas. Antes de los análisis, se verificó la normalidad de todos los datos mediante gráficas de probabilidad, y se verificaron las varianzas iguales mediante la prueba de Bartlett (para respiración) y la prueba de Levine (para productividad), esta última porque los datos de productividad en los rodolitos triturados en el laboratorio exhibieron discrepancias menores de la normalidad. Todos los análisis estadísticos se realizaron con R-Studio v.1.1.463, R v.3.5.2 y SYSTAT v.6.0.

\section{RESUltados}

\section{Efectos del aplastamiento en el laboratorio en la productividad y la respiración de los rodolitos}

La productividad neta fue significativamente diferente entre los rodolitos no perturbados (intactos) $\left(0.032 \pm 0.023 \mathrm{mg} \mathrm{O}_{2} \cdot \mathrm{g}^{-1} \cdot \mathrm{h}^{-1}\right)$, los FRT perturbados por atraques $\left(-0.002 \pm 0.030 \mathrm{mg} \mathrm{O}{ }_{2} \cdot \mathrm{g}^{-1} \cdot \mathrm{h}^{-1}\right)$ y los rodolitos triturados en el laboratorio $\left(0.026 \pm 0.023 \mathrm{mg} \mathrm{O} \cdot \mathrm{g}^{-1} \cdot \mathrm{h}^{-1}\right)$ (ANDEVA: $\left.F_{2,21}=8.468, P=0.002\right)$. Específicamente, la productividad neta fue significativamente menor en los FRT perturbados por atraques que en los rodolitos no perturbados (intactos) (DMS de Fisher: $P=0.001$ ) y en los rodolitos triturados en el laboratorio $(P=0.048)$, pero no difirió entre los rodolitos no perturbados (intactos) y los rodolitos triturados en el laboratorio $(P=0.129)$ (Fig. 2). De hecho, los FRT perturbados por atraques exhibieron una respiración neta, mientras que los rodolitos intactos y los rodolitos que fueron triturados en el laboratorio exhibieron ambos una productividad neta (Fig. 2). Asimismo, la respiración también difirió significativamente entre los rodolitos no perturbados (intactos) $\left(0.040 \pm 0.094 \mathrm{mg} \mathrm{O}_{2} \cdot \mathrm{g}^{-1} \cdot \mathrm{h}^{-1}\right)$, los FRT perturbados por atraques $\left(0.069 \pm 0.019 \mathrm{mg} \mathrm{O}_{2} \cdot \mathrm{g}^{-1} \cdot \mathrm{h}^{-1}\right)$ y los rodolitos triturados en el laboratorio $\left(0.062 \pm 0.016 \mathrm{mg} \mathrm{O} \mathrm{O}_{2} \cdot \mathrm{g}^{-1} \cdot \mathrm{h}^{-1}\right)$ (ANDEVA: $\left.F_{2,21}=4.512, P=0.023\right)$. Específicamente, la respiración fue significativamente mayor en los FRT perturbados por los atraques que en los rodolitos no perturbados (intactos) (DMS de Fisher: $P=0.007$ ), pero no difirió entre los rodolitos no 
Ciencias Marinas, Vol. 46, No. 4, 2020

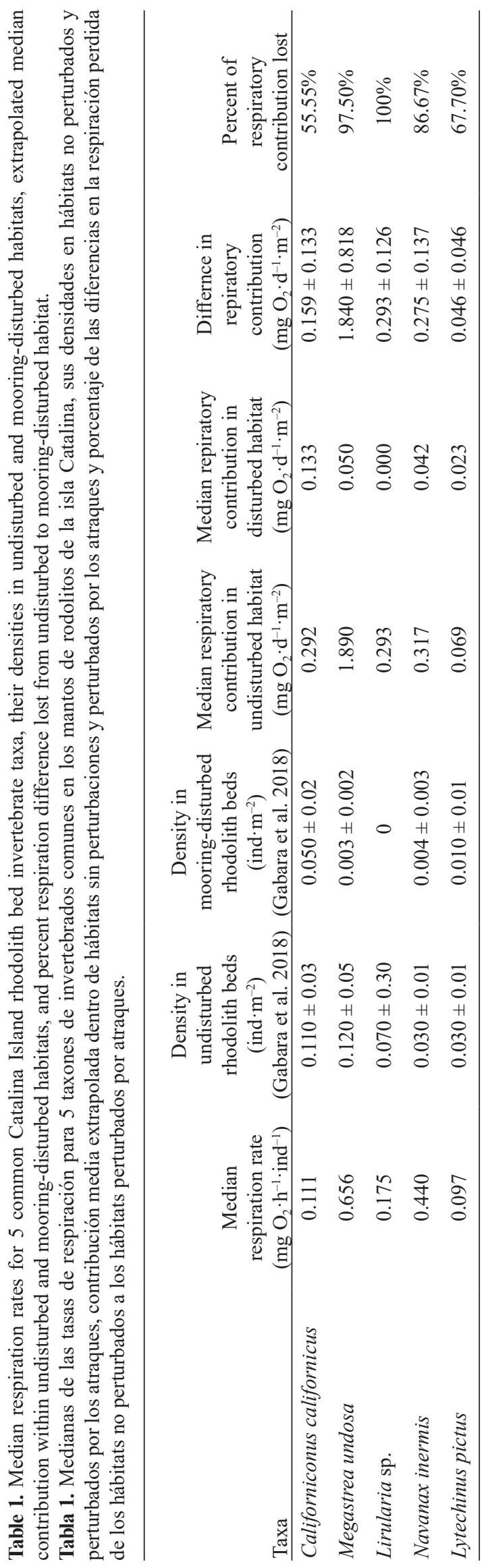




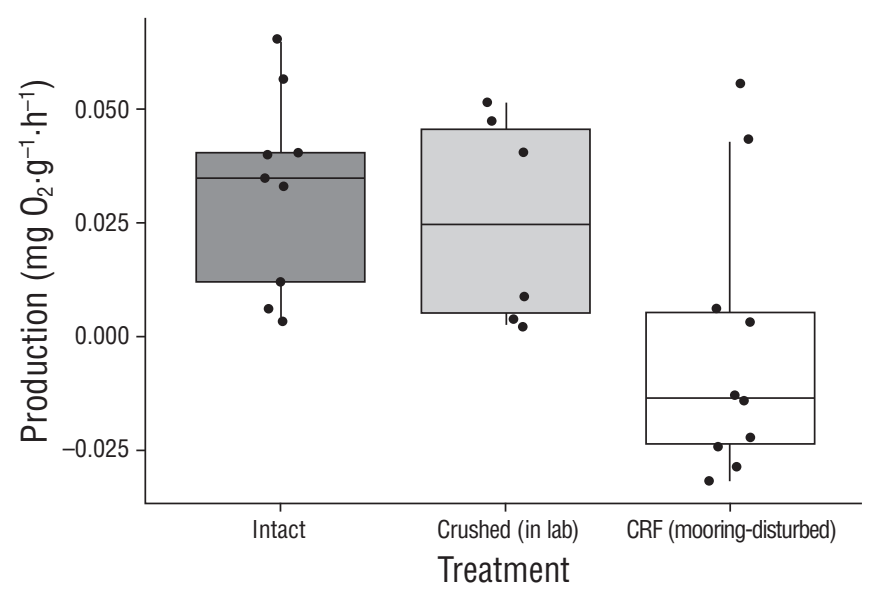

Figure 2. Box plots showing maximum net productivity $\left(\mathrm{mg} \mathrm{O} \mathrm{O}_{2} \cdot \mathrm{g}^{-1} \cdot \mathrm{h}^{-1}\right)$ for undisturbed (intact) rhodoliths, rhodoliths that were experimentally crushed in the laboratory, and mooringdisturbed crushed rhodolith fragments (CRF). Positive values reflect net productivity (i.e., oxygen production) and negative values reflect net respiration (i.e., oxygen consumption). Horizontal lines represent median values.

Figura 2. Diagramas de caja que muestran la productividad neta máxima $\left(\mathrm{mg} \mathrm{O}_{2} \cdot \mathrm{g}^{-1} \cdot \mathrm{h}^{-1}\right)$ para los rodolitos no perturbados (intactos), los rodolitos que fueron triturados experimentalmente en el laboratorio y los fragmentos de rodolitos triturados (CRF) perturbados por los atraques. Los valores positivos reflejan la productividad neta (i.e., la producción de oxígeno) y los valores negativos reflejan la respiración neta (i.e., el consumo de oxígeno). Las líneas horizontales representan valores de las medianas.

undisturbed (intact) rhodoliths $\left(0.040 \pm 0.094 \mathrm{mg} \mathrm{O}_{2} \cdot \mathrm{g}^{-1} \cdot \mathrm{h}^{-1}\right)$, the mooring-disturbed CRF $\left(0.069 \pm 0.019 \mathrm{mg} \mathrm{O} \cdot \mathrm{g}^{-1} \cdot \mathrm{h}^{-1}\right)$, and the laboratory-crushed rhodoliths $(0.062 \pm 0.016 \mathrm{mg}$ $\mathrm{O}_{2} \cdot \mathrm{g}^{-1} \cdot \mathrm{h}^{-1}$ ) (ANOVA: $F_{2,21}=4.512, P=0.023$ ). Specifically, respiration was significantly greater in the mooring-disturbed CRF than in the undisturbed (intact) rhodoliths (Fisher's LSD: $P=0.007)$, but it did not differ between the undisturbed (intact) rhodoliths and the laboratory-crushed rhodoliths $(P=0.322)$, or between the mooring-disturbed $\mathrm{CRF}$ and the laboratory-crushed rhodoliths $(P=0.112)$ (Fig. 3). Further, although a general trend was observed in that crushing of the rhodoliths in the laboratory appeared to lead to slight decreases in net productivity and slight increases in respiration (Fig. 4), no significant differences were observed between pre- and post-crushing for either net productivity (paired $t$-test: $\left.t_{7}=-1.894, P=0.100\right)$ or respiration $\left(t_{7}=0.265\right.$, $P=0.799)$.

\section{Quantifying rhodolith-associated invertebrate respiration}

Respiration rates differed among the 5 epibenthic invertebrate taxa studied (Fig. 5). When considered on an individual basis, respiration rates ranged between $0.097 \mathrm{mg}$ $\mathrm{O}_{2} \cdot \mathrm{g}^{-1} \cdot$ ind $^{-1} \cdot \mathrm{h}^{-1}$ (L. pictus) and $0.656 \mathrm{mg} \mathrm{O} \cdot \mathrm{g}^{-1} \cdot$ ind $^{-1} \cdot \mathrm{h}^{-1}$ (M. undosa) (Table 1). These respiration values are perturbados (intactos) y los rodolitos triturados en el laboratorio $(P=0.322)$, o entre los FRT perturbados por los atraques y los rodolitos triturados en el laboratorio $(P=0.112)$ (Fig. 3). Además, aunque se observó una tendencia general de que la trituración de los rodolitos en el laboratorio parecía producir pequeñas disminuciones en la productividad neta y pequeños aumentos en la respiración (Fig. 4), no se observaron diferencias significativas entre la trituración previa y la posterior tanto para la productividad neta (prueba $t$ pareada: $\left.t_{7}=-1.894, P=0.100\right)$ como para la respiración $\left(t_{7}=0.265\right.$, $P=0.799)$.

\section{Cuantificación de la respiración de los invertebrados asociados a los rodolitos}

Las tasas de respiración difirieron entre los 5 taxones de invertebrados epibentónicos estudiados (Fig. 5). Cuando se consideraron de manera individual, las tasas de respiración variaron entre $0.097 \mathrm{mg} \mathrm{O}{ }_{2} \cdot \mathrm{g}^{-1} \cdot$ ind $^{-1} \cdot \mathrm{h}^{-1}$ (L. pictus) y $0.656 \mathrm{mg} \mathrm{O}_{2} \cdot \mathrm{g}^{-1} \cdot$ ind $^{-1} \cdot \mathrm{h}^{-1}$ (M. undosa) (Tabla 1). Estos valores de respiración son significativos dado que los rodolitos usados en este estudio tenían un tamaño promedio de entre $1.51 \pm 0.66 \mathrm{~g}$ ph y $1.80 \pm 0.91 \mathrm{~g}$ ph (medias \pm error estándar) y exhibieron valores de respiración de entre $0.040 \pm$ $0.094 \mathrm{mg} \mathrm{O} \cdot \mathrm{g}^{-1} \cdot \mathrm{h}^{-1}$ (para no triturados) y $0.069 \pm 0.019 \mathrm{mg}$ $\mathrm{O}_{2} \cdot \mathrm{g}^{-1} \cdot \mathrm{h}^{-1}$ (para FRT) (ver arriba), y por lo tanto deben ser considerados al modelar la respiración del ecosistema.

\section{Discusión}

Nuestros resultados muestran que el aplastamiento crónico de los talos de los rodolitos por las cadenas de los atraques de embarcaciones altera los patrones del metabolismo de los rodolitos. Los FRT recolectados del hábitat donde las cadenas de atraque perturbaban repetidamente el bentos presentaron una tasa de respiración mayor que los rodolitos intactos que se recolectaron del manto de rodolitos no perturbado adyacente. Aunque la razón de esto permanece incierta, esto puede deberse a alteraciones en su estructura tridimensional, la cual se pierde cuando los rodolitos se trituran y forman fragmentos. Como resultado, los pigmentos fotosintéticos dentro de sus interiores son expuestos a alta luminosidad, $\mathrm{y}$ es probable que aumente la fotorrespiración, como fue reportado por Kim et al. (2020). En consecuencia, las tasas de productividad neta máxima fueron menores en los FRT que en los rodolitos intactos. Sin embargo, nuestros experimentos de laboratorio sugieren que los cambios en la productividad y la respiración de los rodolito no fueron detectables inmediatamente después de la trituración. Esto nos lleva a concluir que la trituración de los talos de los rodolitos por sí sola no produce cambios inmediatos en la productividad neta o la respiración. En cambio, la perturbación repetida de los rodolitos por el aplastamiento crónico por las cadenas de los atraques a lo largo del tiempo conduce a su mortalidad y degrada el hábitat. Esto ocasiona una disminución de 
significant given that the rhodoliths used in this study averaged in size between $1.51 \pm 0.66 \mathrm{~g} \mathrm{ww}$ and $1.80 \pm$ $0.91 \mathrm{~g}$ ww (means $\pm \mathrm{SE}$ ) and exhibited respiration values between $0.040 \pm 0.094 \mathrm{mg} \mathrm{O}_{2} \cdot \mathrm{g}^{-1} \cdot \mathrm{h}^{-1}$ (for uncrushed) and $0.069 \pm 0.019 \mathrm{mg} \mathrm{O}{ }_{2} \cdot \mathrm{g}^{-1} \cdot \mathrm{h}^{-1}$ (for CRF) (see above), and therefore should be considered when modelling ecosystem respiration.

\section{Discussion}

Our results show that the chronic crushing of rhodolith thalli by boat mooring chains alters patterns of rhodolith metabolism. Crushed rhodolith fragments (CRF) collected from the habitat where mooring chains repeatedly disturbed the benthos respired at a higher rate than intact rhodoliths that were collected from the adjacent undisturbed rhodolith bed. While the reason for this remains unclear, this may be due to alterations to their three-dimensional structure, which is lost when the rhodoliths are crushed into fragments. As a result, the photosynthetic pigments within their interiors are exposed to high light, and photorespiration likely increases as reported by Kim et al. (2020). Consequently, maximum net productivity rates were lower in CRF than in intact rhodoliths. However, our laboratory experiments suggest that changes to rhodolith productivity and respiration were not detectable immediately following crushing. This leads us to conclude that crushing of the rhodolith thalli alone does not result in immediate changes to the net productivity or respiration. Instead, repeated disturbance to the rhodoliths by chronic crushing from mooring chains over time leads to their mortality and degrades the habitat. This results in a reduction in net productivity and an increase in respiration by the rhodoliths. Further, our findings also suggest that over time, with frequent mooring disturbance, rhodolith habitats likely shift to becoming increasingly respiration dominated, which may alter DO levels within the ecosystem. This pattern is likely enhanced when the entire benthic communities, including rhodolith-associated microbes (e.g., Cavalcanti et al. 2018), are considered (del Giorgio et al. 1997, Duarte and Agustí 1998). Consequently, similar to what was found in kelp forest ecosystems (e.g., Castorani et al. 2018), disturbance frequency may be more important than disturbance magnitude in determining the physiological response of rhodoliths to mooring chain impacts.

Our study found that the epibenthic invertebrates inhabiting rhodolith beds have respiration rates that differ both on individual and mass-specific levels. This suggests that invertebrate consumers differentially contribute to respiration (oxygen consumption) and overall community metabolism. When individual-based respiration rates of the invertebrate taxa studied were combined with estimates of each species' abundance in the rhodolith beds and the degraded rhodolith habitats (see Gabara et al. 2018), our data suggest that disturbance-related reductions in the abundance of these 5 species resulted in reduced ecosystem respiration by

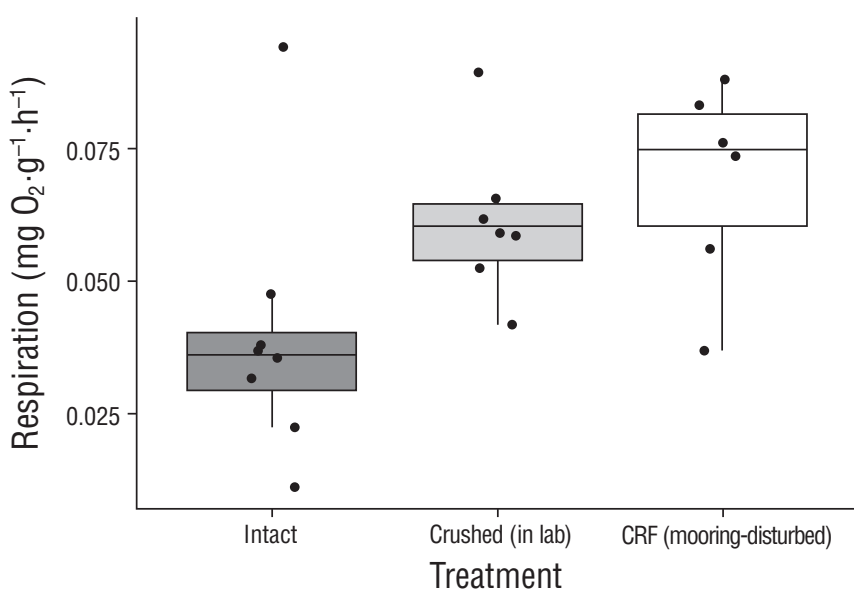

Figure 3. Box plots showing respiration $\left(\mathrm{O}_{2} \cdot \mathrm{g}^{-1} \cdot \mathrm{h}^{-1}\right)$ measured for undisturbed (intact) rhodoliths, rhodoliths that were experimentally crushed in the laboratory, and mooring-disturbed crushed rhodolith fragments (CRF). Although respiration is often displayed as negative values (i.e., oxygen consumption), we report positive values here for ease of interpretation; thus, greater respiration is reflected as being elevated along the $y$-axis. Horizontal lines represent median values ( $n=6$ to 10 each), and vertical whiskers reflect the range where $75 \%$ of all values are expected to fall.

Figura 3. Diagramas de caja que muestran la respiración ( $\mathrm{mg} \mathrm{O}_{2} \cdot \mathrm{g}^{-1} \cdot \mathrm{h}^{-1}$ ) medida para los rodolitos no perturbados (intactos), los rodolitos que fueron triturados experimentalmente en el laboratorio y los fragmentos de rodolitos triturados (CRF) perturbados por los atraques. Aunque la respiración a menudo se muestra como valores negativos (i.e., consumo de oxígeno), aquí reportamos valores positivos para facilitar la interpretación; por tanto, una mayor respiración se refleja como elevada a lo largo del eje $y$. Las líneas horizontales representan los valores de las medianas ( $n=6$ a 10 cada una), y las marcas verticales reflejan el rango donde se espera que se presenten el $75 \%$ de todos los valores.

la productividad neta y un aumento de la respiración de los rodolitos. Además, nuestros hallazgos también sugieren que, con el tiempo, las frecuentes perturbaciones por atraques probablemente ocasionan que los hábitats de los rodolitos cambien y sean cada vez más dominados por la respiración, lo que puede alterar los niveles de OD dentro del ecosistema. Es probable que este patrón sea más evidente si se consideran todas las comunidades bentónicas (del Giorgio et al. 1997, Duarte y Agustí 1998), incluidos los microbios asociados a los rodolitos (e.g., Cavalcanti et al. 2018). En consecuencia, de manera similar a lo que se encontró en los ecosistemas de bosques de algas marinas (e.g., Castorani et al. 2018), la frecuencia de las perturbaciones puede ser más importante que la magnitud de las perturbaciones para determinar la respuesta fisiológica de los rodolitos ante los impactos de las cadenas de atraques.

Nuestro estudio encontró que los invertebrados epibentónicos que habitan los mantos de rodolitos tienen tasas de respiración que difieren tanto a nivel individual como a nivel 
approximately $-2.613 \mathrm{mg} \mathrm{O}_{2} \cdot \mathrm{m}^{-2} \cdot \mathrm{d}^{-1}$, with individual species contributing between $-0.046 \mathrm{mg} \mathrm{O} \cdot \mathrm{m}^{-2} \cdot \mathrm{d}^{-1}$ (L. pictus) and $-1.84 \mathrm{mg} \mathrm{O}_{2} \cdot \mathrm{m}^{-2} \cdot \mathrm{d}^{-1}$ (M. undosa) (Table 1).

The gastropod $C$. californicus and the echinoderm L. pictus had the lowest individual respiration rates, while the gastropod C. californicus had the lowest mass-specific respiration rate. However, despite their low respiration values, at high densities these taxa may alter ecosystem respiration within the rhodolith beds. Both of these organisms may be able to tolerate low oxygen levels in rhodolith bed sediments, as they are often found within the infaunal communities. This also suggests that the organisms with the highest respiration rates, namely $N$. inermis and $M$. undosa, are likely constrained to the surface epibenthic habitat where they are commonly found. This is supported by Grall et al. (2006), who found that rhodolith-associated organisms partition themselves with depth, and by Diaz and Rosenberg (1995) and Altieri and Diaz (2019), who observed that in soft sediment systems like the Chesapeake Bay, hypoxia $\left(<2.8 \mathrm{mg} \mathrm{O}^{2} \cdot \mathrm{L}^{-1}\right)$ occurs annually during summer, causing mortality and emigration by many of the organisms that live there. However, it remains unknown if the epibenthic invertebrates in the rhodolith beds on Catalina Island partition específico de masas. Esto sugiere que los consumidores invertebrados contribuyen de manera diferenciada a la respiración (consumo de oxígeno) y al metabolismo general de la comunidad. Al combinar las tasas de respiración individuales de los taxones de invertebrados estudiados con las estimaciones de abundancia de cada especie en los mantos de rodolitos y los hábitats degradados de rodolitos (ver Gabara et al. 2018), nuestros datos sugieren que la reducción de la abundancia de estas 5 especies relacionada con las perturbaciones ocasionó una reducción de la respiración del ecosistema de aproximadamente $-2.613 \mathrm{mg} \mathrm{O}_{2} \cdot \mathrm{m}^{-2} \cdot \mathrm{d}^{-1}$, con contribuciones por especie de entre $-0.046 \mathrm{mg} \mathrm{O} \cdot \mathrm{m}^{-2} \cdot \mathrm{d}^{-1}$ (L. pictus) $\mathrm{y}-1.84 \mathrm{mg} \mathrm{O}_{2} \cdot \mathrm{m}^{-2} \cdot \mathrm{d}^{-1}$ (M. undosa) (Tabla 1 ).

El gasterópodo $C$. californicus y el equinodermo L. pictus presentaron las tasas de respiración individuales más bajas, mientras que el gasterópodo C. californicus presentó la tasa de respiración específica de masa más baja. Sin embargo, a pesar de sus bajos valores de respiración, a altas densidades, estos taxones pueden alterar la respiración del ecosistema dentro de los mantos de rodolitos. Ambos organismos podrían ser capaces de tolerar niveles bajos de oxígeno en los sedimentos de los mantos de rodolitos, ya que a menudo se encuentran dentro de las comunidades infaunales. Esto

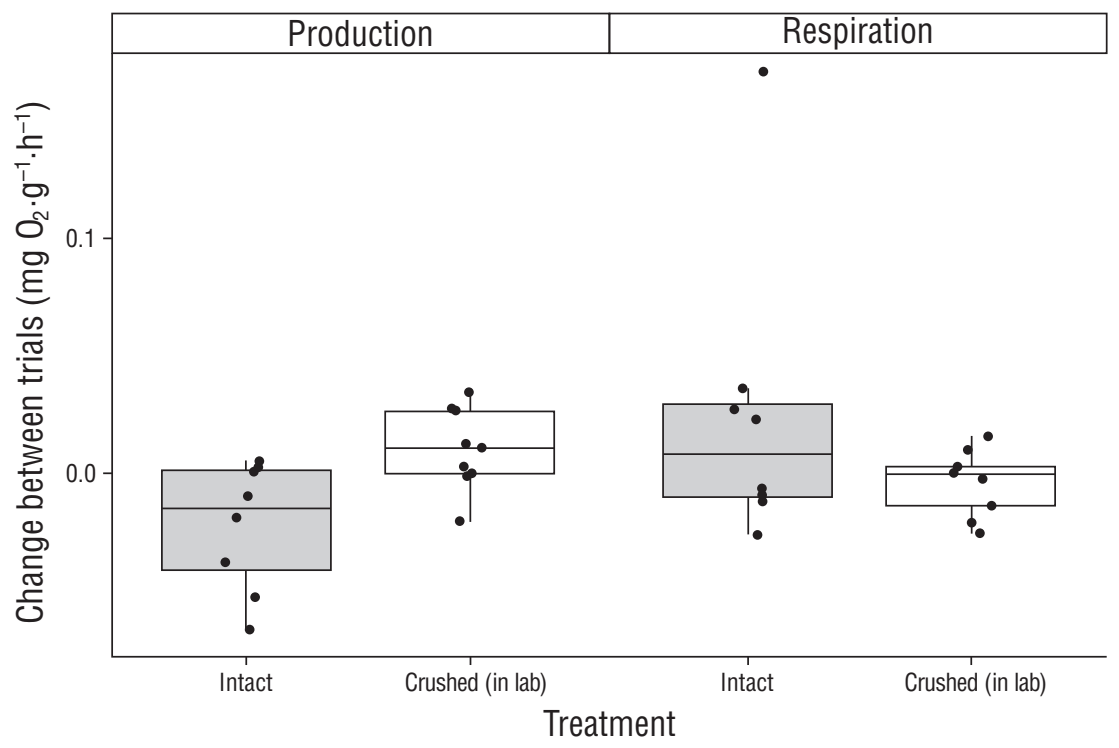

Figure 4. Box plots showing the changes in net productivity and respiration in rhodoliths following experimental crushing in the laboratory (i.e., crushed) and between the first and second measurements for undisturbed (intact) rhodoliths. The intact rhodoliths were measured a second time to serve as a procedural control for the crushing experiment (i.e., to evaluate if any changes in productivity or respiration between pre- and post-crushing were simply due to re-measuring the rhodoliths). Negative values reflect a loss of productivity and/or respiration and positive values reflect an increase in these measures. Black horizontal bars reflect median rates ( $n=6$ to 10 each).

Figura 4. Diagramas de caja que muestran los cambios en la productividad neta y la respiración en los rodolitos después de la trituración experimental en el laboratorio (i.e., triturados) y entre la primera y la segunda medición de los rodolitos no perturbados (intactos). Los rodolitos intactos se midieron por segunda vez para que sirvieran como control de procedimiento para el experimento de trituración (i.e., para evaluar si los cambios en la productividad o la respiración entre la trituración previa y la posterior se debían simplemente a medir los rodolitos otra vez). Los valores negativos reflejan una pérdida de la productividad y/o respiración y los valores positivos reflejan un aumento en estas medidas. Las barras horizontales negras reflejan las medianas de las tasas ( $n=6$ a 10 cada una). 

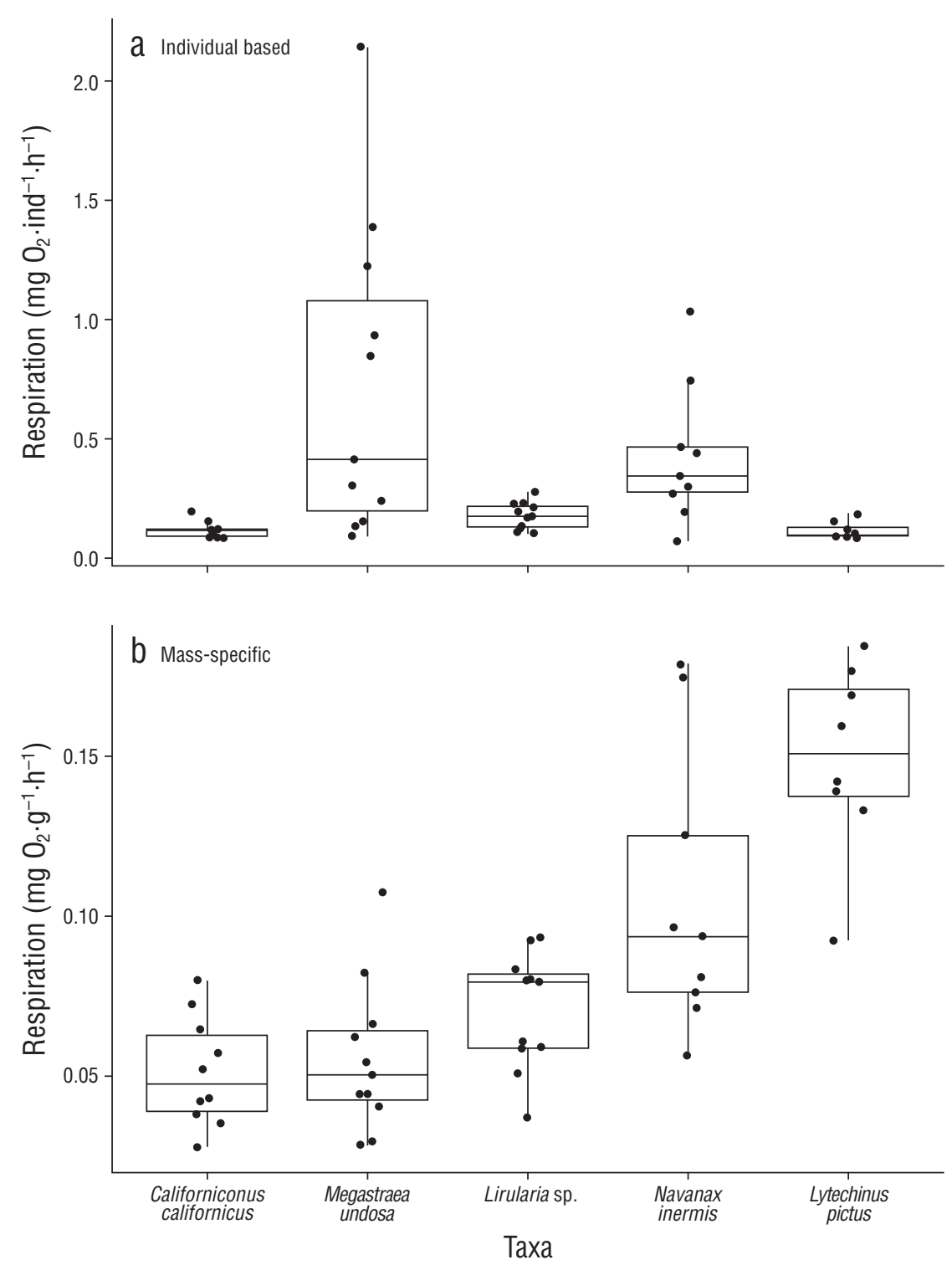

Figure 5. Individual-based respiration rates (a) and mass-specific respiration rates (b) for the 5 most commonly observed epibenthic invertebrate taxa in the rhodolith beds at Catalina Island. Black horizontal bars reflect median rates $(n=10$ each).

Figura 5. Tasas de respiración basadas en individuos (a) y tasas de respiración específicas de masa (b) para los 5 taxones de invertebrados epibentónicos más comúnmente observados en los mantos de rodolitos en la isla Catalina. Las barras horizontales negras reflejan las medianas de las tasas ( $n=10$ cada una).

themselves within the rhodolith bed matrix based on oxygen availability and/or their oxygen consumption. What is known is that these taxa are not generally replaced by other taxa in the crushed rhodolith habitat who would compensate for this lost respiration, but rather the rhodoliths beds support higher overall organism abundances than the crushed rhodolith habitats (Gabara et al. 2018).

This study takes steps towards creating a more individualized community model for rhodolith primary productivity and respiration in both undisturbed and mooring-disturbed (degraded) rhodolith beds. Thus, our estimates for rhodolith también sugiere que los organismos con las tasas de respiración más altas, es decir $N$. inermis y $M$. undosa, probablemente estén limitados al hábitat epibentónico superficial donde se encuentran comúnmente. Esto es apoyado por los hallazgos de Grall et al. (2006), quienes encontraron que los organismos asociados a los rodolitos se dividen con la profundidad, y Díaz y Rosenberg (1995) y Altieri y Diaz (2019), quienes observaron que, en sistemas de sedimentos blandos como la bahía de Chesapeake, la hipoxia $\left(<2.8 \mathrm{mg} \mathrm{O}_{2} \cdot \mathrm{L}^{-1}\right)$ ocurre anualmente durante el verano y provoca la mortalidad y la emigración de muchos de los organismos que habitan 
production and respiration and invertebrate respiration can give a preliminary context for field-based community estimates. Field-based estimates of production and respiration are needed that incorporate both flora and fauna within communities in undisturbed and mooring-disturbed habitats under natural conditions. Future studies could determine if biomass-specific estimates of productivity and respiration in the lab can be scaled by each species' biomass in the field to match production and respiration rates measured in situ (e.g., using benthic chambers), such as described by Middelboe et al. (2006). A better understanding of the individual contributions of production and respiration by the dominant taxa relative to whole-community estimates will also reveal if all contributions are characterized properly. If not, less conspicuous members of the community (e.g., microbes and rarer taxa, or smaller but numerically abundant taxa) may have greater contributions to community metabolism than previously thought. For example, the microbiome associated with live rhodoliths from Catalina Island differs from that of dead rhodoliths (e.g., crushed rhodoliths sands), with live rhodoliths supporting a diverse array of taxa that includes Cyanobacteria, Actinobacteria, Betaproteobacteria, Clostridia, and Gammaproteobacteria, and dead rhodoliths being dominated by Gammaproteobacteria (Cavalcanti et al. 2018).

Future studies can build off our methods for measuring temporal effects of mooring crushing by monitoring these effects in the lab and/or the field over greater frequencies and over longer time scales. In addition, future studies can quantify respiration rates for additional taxa that inhabit the rhodolith beds, specifically macro- and microscopic infaunal invertebrates such as tanaids, ostracods, caprellids, and gammarids. These organisms can occur in the densities of over 10,000 per square meter and therefore may make significant respiratory contributions despite their small size and biomass (Gabara et al. 2018). Given that rhodolith physiology varies seasonally (Martin et al. 2007) and over wide temperature ranges (Steller et al. 2007), expanding these experiments over wider temporal scales will broaden the application of these results.

\section{ACKNOWLEDGMents}

We are grateful for the funding provided by a grant from California Sea Grant to DS and ME (RHCE-04BTR). Permission to collect rhodoliths and invertebrates was provided by CA Fish \& Wildlife Entity Permit \#SC-751. We would like to thank Trevor Oudin, Lauren Czarnecki Oudin, Eric Castillo, Kellie Spafford, and the staff at USC WIES for facilitating field and lab-based science. We are especially grateful to Darrin Ambat, who assisted with all aspects of this study, and to Natalie Goetz and Joseph Matthews, who assisted with field collection of rhodoliths and invertebrates and the laboratory measurements of their productivity and respiration, and for laboratory and diving support from SDSU and MLML Beer Pigs. ahí. Sin embargo, aún se desconoce si los invertebrados epibentónicos en los mantos de rodolitos en la isla Catalina se dividen dentro de la matriz de mantos de rodolitos en función de la disponibilidad de oxígeno y/o su consumo de oxígeno. Lo que se sabe es que estos taxones generalmente no son reemplazados por otros taxones del hábitat de rodolitos triturados que compensarían esta respiración perdida, sino que los mantos de rodolitos sustentan una mayor abundancia general de organismos que los hábitats de rodolitos triturados (Gabara et al. 2018).

Este estudio es un avance hacia la creación de un modelo comunitario más individualizado para la productividad primaria y la respiración de rodolitos tanto en los mantos de rodolitos no perturbados como en los mantos perturbados por atraques (degradados). Por lo tanto, nuestras estimaciones de la producción y respiración de los rodolitos y la respiración de los invertebrados pueden dar un contexto preliminar para las estimaciones de comunidades basadas en observaciones de campo. Se necesitan estimaciones de la producción y la respiración basadas en observaciones de campo que incorporen tanto la flora como la fauna dentro de las comunidades en hábitats no perturbados y perturbados por atraques en condiciones naturales. Estudios en el futuro podrían determinar si las estimaciones de la productividad y la respiración de una biomasa específica en el laboratorio se pueden extrapolar con la biomasa de cada especie en el campo para que correspondan con las tasas de producción y respiración medidas in situ (e.g., usando cámaras bentónicas), como lo describieron Middelboe et al. (2006). Un mejor entendimiento sobre las contribuciones individuales de los taxones dominantes a la producción y la respiración con relación a las estimaciones para toda la comunidad también revelará si todas las contribuciones están caracterizadas de manera adecuada. Si no, los miembros menos conspicuos de la comunidad (e.g., microbios y taxones menos comunes, o taxones más pequeños pero numéricamente abundantes) pueden estar contribuyendo más de lo que se pensaba al metabolismo de la comunidad. Por ejemplo, el microbioma asociado a los rodolitos vivos de la isla Catalina difiere del de los rodolitos muertos (e.g., arenas de rodolitos triturados); los rodolitos vivos sustentan una amplia gama de taxones que incluye cianobacterias, actinobacterias, betaproteobacterias, clostridios y gammaproteobacterias, mientras que los rodolitos muertos están dominados por gammproteobacterias (Cavalcanti et al. 2018).

Los estudios futuros pueden aunar a nuestros métodos para medir los efectos temporales del aplastamiento por atraques monitoreando estos efectos en el laboratorio y/o en el campo con mayores frecuencias y en escalas de tiempo más largas. Además, los estudios futuros pueden cuantificar las tasas de respiración de más taxones que habitan los mantos de rodolitos, específicamente invertebrados infaunales macroscópicos y microscópicos como tanaidáceos, ostrácodos, caprélidos y gammáridos. Estos organismos pueden presentar densidades de más de 10,000 individuos 


\section{REFERENCES}

Airoldi L, Balata D, Beck MW. 2008. The gray zone: relationships between habitat loss and marine diversity and their applications in conservation. J Exp Mar Biol Ecol. 366(1-2):8-15. https://doi.org/10.1016/j.jembe.2008.07.034

Altieri AH, Diaz RJ. 2019. Dead Zones: Oxygen depletion in coastal ecosystems. In: Sheppard C (ed.), World Seas: An Environmental Evaluation. 2nd Ed. London (UK): Academic Press. (Volume 3: Ecological issues and environmental impacts). $666 \mathrm{p}$. https://doi.org/10.1016/B978-0-12-805052-1.00021-8

Bosence DWJ. 1983. The occurrence and ecology of recent rhodoliths-A review. In: Peryt TM (ed.), Coated Grains. Berlin, Heidelberg: Springer. p. 225-242. https://doi.org/10.1007/978-3-642-68869-0 20

Brey T. 2010. An emperical model for estimating aquatic invertebrate respiration. Methods Ecol Evol. 1(1):92-101. https://doi.org/10.1111/j.2041-210x.2009.00008.x

Castorani MCN, Reed DC, Miller RJ. 2018. Loss of foundation species: disturbance frequency outweighs severity in structuring kelp forest communities. Ecology. 99(11):2442-2454. https://doi.org/10.1002/ecy.2485

Cavalcanti GS, Shukla P, Morris M, Ribeiro B, Foley M, Doane MP, Thompson CC, Edwards MS, Dinsdale EA, Thompson FL. 2018. Rhodoliths holobionts in a changing ocean: Host-microbes interactions mediate coralline algae resilience under ocean acidification. BMC Genomics. 19(1):701. https://doi.org/10.1186/s12864-018-5064-4

Connell JH. 1978. Diversity in tropical rain forests and coral reefs. Science. 199(4335):1302-1310. https://doi.org/10.1126/science.199.4335.1302

Del Giorgio PA, Cole JJ, Cimbleris A. 1997. Respiration rates in bacteria exceed phytoplankton production in unproductive aquatic systems. Nature. 385(6612):148-151. https://doi.org/10.1038/385148a0

Diaz RJ, Rosenberg R. 1995. Marine benthic hypoxia: a review of its ecological effects and the behavioural responses of benthic macrofauna. Oceanog Mar Biol Ann Rev. 33:245-303.

Duarte CM, Agustí S. 1998. The $\mathrm{CO}_{2}$ balance of unproductive aquatic ecosystems. Science. 281(5374):234-236. https://doi.org/10.1126/science.281.5374.234

Edwards M, Konar B, Kim J-H, Gabara S, Sullaway G, McHugh T, Spector M, Small S. 2020. Marine deforestation leads to widespread loss of ecosystem function. PLOS ONE. 15(3):e0226173. https://doi.org/10.1371/journal.pone.0226173

Edwards MS, Estes JA. 2006. Catastrophe, recovery and range limitation in NE Pacific kelp forests: a large-scale perspective. Mar Ecol Progr Ser. 320:79-87. https://doi.org/10.3354/meps320079

Ellison AM, Bank MS, Clinton BD, Colburn EA, Elliott K, Ford CR, Foster DR, Kloeppel BD, Knoepp JD, Lovett GM, et al. 2005. Loss of foundation species: consequences for the structure and dynamics of forested ecosystems. Front Ecol Environ. 3(9):479-486.

https://doi.org/10.1890/1540-9295(2005)003[0479:lofscf]2.0.co;2 Foster MS. 2001. Rhodoliths: between rocks and soft places. J Phycol. 37(5):659-667. https://doi.org/10.1046/j.1529-8817.2001.00195.x

Gabara SS. 2020. Trophic structure and potential carbon and nitrogen flow of a rhodolith bed at Santa Catalina Island inferred from stable isotopes. Mar Biol. 167(3):30. https://doi.org/10.1007/s00227-019-3635-9

Gabara SS, Hamilton SL, Edwards MS, Steller DL. 2018. Rhodolith structural loss decreases abundance, diversity, and stability of por metro cuadrado y, por lo tanto, pueden realizar contribuciones respiratorias significativas a pesar de su tamaño y biomasa pequeña (Gabara et al. 2018). Dado que la fisiología de los rodolitos varía estacionalmente (Martin et al. 2007) y en amplios intervalos de temperatura (Steller et al. 2007), expandir estos experimentos a mayores escalas temporales ampliará la aplicación de estos resultados.

\section{Agradecimientos}

Agradecemos el financiamiento proporcionado a través de una beca de California Sea Grant a DS y ME (RHCE04BTR). El permiso para recolectar rodolitos e invertebrados fue otorgado por el Fish \& Wildlife Entity Permit de CA \#SC-751. Nos gustaría agradecer la facilitación de la ciencia de campo y de laboratorio proporcionada por Trevor Oudin, Lauren Czarnecki Oudin, Eric Castillo, Kellie Spafford y el personal de USC WIES. Estamos especialmente agradecidos con Darrin Ambat, quien asistió con todos los aspectos de este estudio, y con Natalie Goetz y Joseph Matthews por su ayuda con la recolección de los rodolitos e invertebrados en el campo y la medición de la productividad y la respiración en el laboratorio, y con SDSU y MLML Beer Pigs por el apoyo de laboratorio y buceo.

Traducido al español por Claudia Michel-Villalobos.

benthic communities at Santa Catalina Island, CA. Mar Ecol Prog Ser. 595:71-88.

https://doi.org/10.3354/meps12528

Graham MH. 2004. Effects of local deforestation on the diversity and structure of southern California giant kelp forest food webs. Ecosystems. 7(4):341-357.

https://doi.org/10.1007/s10021-003-0245-6

Graham MH, Fox MD, Hamilton SL. 2016. Macrophyte productivity and the provisioning of energy and habitat to nearshore systems. In: Ólafsson (ed.), Marine Macrophytes as Foundation Species. Boca Raton (FL): CRC Press. p. 131-160. https://doi.org/10.4324/9781315370781-7

Graham MH, Vásquez JA, Buschmann AH. 2007. Global ecology of the giant kelp Macrocystis: from ecotypes to ecosystems. Oceanog Mar Biol. 45:39-88. https://doi.org/10.1201/9781420050943.ch2

Grall J, Le Loc'h F, Guyonnet B, Riera P. 2006. Community structure and food web based on stable isotopes $\left(\delta^{15} \mathrm{~N}\right.$ and $\left.\delta^{13} \mathrm{C}\right)$ analysis of a North Eastern Atlantic maerl bed. J Exp Mar Biol Ecol. 338(1):1-15. https://doi.org/10.1016/j.jembe.2006.06.013

Hall-Spencer JM, Moore PG. 2000. Scallop dredging has profound, long-term impacts on maerl habitats. ICES J Mar Sci. 57(5):1407-1415. https://doi.org/10.1006/jmsc.2000.0918

Hobbs RJ, Huenneke LF. 1992. Disturbance, diversity, and invasion: implications for conservation. Cons Biol. 6(3):324-337. https://doi.org/10.1046/j.1523-1739.1992.06030324.x

Jones CG, Lawton JH, Shachak M. 1994. Organisms as ecosystem engineers. Oikos. 69(3):373-386.

https://doi.org/10.2307/3545850 
Kamenos NA, Moore PG, Hall-Spencer JM. 2004a. Nursery-area function of maerl grounds for juvenile queen scallops Aequipecten opercularis and other invertebrates. Mar Ecol Prog Ser. 274:183-189.

https://doi.org/10.3354/meps274183

Kamenos NA, Moore PG, Hall-Spencer JM. 2004b. Maerl grounds provide both refuge and high growth potential for juvenile queen scallops (Aequipecten opercularis L.). J Exp Mar Biol Ecol. 313(2):241-254.

https://doi.org/10.1016/j.jembe.2004.08.007

Kim JH, Steller DL, Edwards MS. 2020. Variation in photosynthetic performance relative to thallus microhabitat heterogeneity in Lithothamnion australe (rhodophyta, corallinales) rhodoliths. J Phycol. https://oi.org/10.1111/jpy.13080

Luckhurst BE, Luckhurst K. 1978. Analysis of the influence of substrate variables on coral reef fish communities. Mar Biol. 49(4):317-323. https://doi.org/10.1007/bf00455026

Mao J, Burdett HL, McGill RAR, Newton J, Gulliver P, Kamenos NA. 2020. Carbon burial over the last four millennia is regulated by both climatic and land use change. Glob Change Biol. 26(4):2496-2504. https://doi.org/10.1111/gcb.15021

Martin S, Clavier J, Chauvaud L, Thouzeau G. 2007. Community metabolism in temperate maerl beds. I. Carbon and carbonate fluxes. Mar Ecol Prog Ser. 335:19-29. https://doi.org/10.3354/meps335019

McConnico LA, Hernández-Carmona G, Riosmena-Rodríguez R. 2018. Nutrient production in rhodolith beds: impact of a foundation species and its associates. Mar Ecol Prog Ser. 590:53-66. https://doi.org/10.3354/meps12513

Middelboe AL, Sand-Jensen K, Binzer T. 2006. Highly predictable photosynthetic production in natural macroalgal communities from incoming and absorbed light. Oecologia. 150(3):464-476. https://doi.org/10.1007/s00442-006-0526-9

Nagelkerken I, Blaber SJM, Bouillon S, Green P, Haywood M, Kirton LG, Meynecke JO, Pawlik J, Penrose HM, Sasekumar A, Somerfield PJ. 2008. The habitat function of mangroves for terrestrial and marine fauna: A review. Aqu Bot. 89(2):155-185. https://doi.org/10.1016/j.aquabot.2007.12.007

Newell RC. 1973. Factors affecting the respiration of intertidal invertebrates. Am Zool. 13(2):513-528. https://doi.org/10.1093/icb/13.2.513
Orth RJ, Heck KL, van Montfrans J. 1984. Faunal communities in seagrass beds: a review of the influence of plant structure and prey characteristics on predator-prey relationships. Estuaries. 7(4):339-350. https://doi.org/10.2307/1351618

Pickett ST, White PS. 2013. The ecology of natural disturbance and patch dynamics. 1st ed. New Brunswick (NJ):Elsevier. 472 p.

Steller DL, Cáceres-Martínez C. 2009. Coralline algal rhodoliths enhance larval settlement and early growth of the Pacific calico scallop Argopecten ventricosus. Mar Ecol Prog Ser. 396:49-60. https://doi.org/10.3354/meps08261

Steller DL, Foster MS. 1995. Environmental factors influencing distribution and morphology of rhodoliths in Bahía Concepción, B.C.S., México. J Exp Mar Biol Ecol. 194(2): 201-212. https://doi.org/10.1016/0022-0981(95)00086-0

Steller DL, Hernández-Ayón JM, Riosmena-Rodriguez R, CabelloPasini A. 2007. Effect of temperature on photosynthesis, growth and calcification rates of the free-living coralline alga Lithophyllum margaritae $=$ Efecto de la temperatura sobre las tasas de fotosíntesis, crecimiento y calcificación del alga coralina de vida libre Lithophyllum margaritaei. Cienc Mar. 33(4):441-456. https://doi.org/10.7773/cm.v33i4.1255

Steller DL, Riosmena-Rodriguez R, Foster MS, Roberts CA. 2003. Rhodolith bed diversity in the Gulf of California: the importance of rhodolith structure and consequences of disturbance. Aquatic Conservation: Mar Fresh Ecosyst.13(S1):S5-S20. https://doi.org/10.1002/aqc.564

Tompkins PA. 2011. Distribution, growth, and disturbance of Catalina Island rhodoliths [MSc thesis]. Moss Landing (CA): San Jose State University. $28 \mathrm{p}$. https://doi.org/10.31979/etd.vpw7-rnrn

Tompkins PA, Steller DL. 2016. Living carbonate habitats in temperate California (USA) waters: distribution, growth, and disturbance of Santa Catalina Island rhodoliths. Mar Ecol Prog Ser. 560:135-145. https://doi.org/10.3354/meps11919

Worm B, Barbier EB, Beaumont N, Duffy JE, Folke C, Halpern BS, Jackson JBC, Lotze HK, Micheli F, Palumbi SR, et al. 2006. Impacts of biodiversity loss on ocean ecosystem services. Science. 314(5800):787-790. https://doi.org/10.1126/science.1132294

Received March 2020, accepted August 2020. 